\title{
Tradisi Madrasah Tarbiyah Islamiyah di Sumatera Barat
}

\author{
oleh Muhammad Kosim ${ }^{1}$
}

\begin{abstract}
Abstrak: Madrasah Tarbiyah Islamiyah (MTI) merupakan lembaga pendidikan Islam yang berorientasi pada kajian tafaqquh fi al-din serta mempertahankan i'tiqad ahl al-sunnah wa aljama'ah dan bermazhab Syafi'i. MTI tumbuh dan berkembang di Sumatera Barat sehingga tradisi yang berkembang di dalamnya turut dipengaruhi oleh budaya lokal, yaitu Minangkabau. Hal ini menjadi keunikan MTI itu sendiri jika dibandingkan dengan pesantren yang ada di pulau Jawa.
\end{abstract}

\section{Kata Kunci: Tradisi, MTI, Sumatera Barat}

\section{A. Pendahuluan}

Madrasah Tarbiyah Islamiyah, atau disingkat dengan MTI, merupakan lembaga pendidikan Islam bercorak pesantren yang lahir dari Sumatera Barat dan hingga kini berkembang di dalam dan luar Sumatera Barat. MTI sendiri merupakan perubahan dari beberapa lembaga pendidikan surau yang dikelola secara tradisional dan menggunakan sistem halaqah oleh ulama-ulama yang berpaham ahl al-Sunnah wa al-Jama'ah dan bermazhab Syafi'i. Tokoh sentral dari perubahan ini adalah Syekh Sulaiman al-Rasuli atau dikenal dengan Inyiak Canduang. Ia pernah belajar kepada imam masjid al-Haram, Mekah, Syekh Ahmad Khatib al-Minangkabawi selama tiga setengah tahun.

Sekembalinya dari Mekah, ia aktif mendidik di Surau Baru Canduang. Namun, pada tahun 1926, atas usulan ulama yang sepaham dengannya, SyekhAbbas Qadhi Ladang Lawas, beserta murid-muridnya, maka dilakukan perubahan sistem pendidikan halaqah di surau menjadi sistem klasikal. Maka lembaga pendidikan yang ia pimpin diberi nama "Madrasah Tarbiyah Islamiyah". Dua tahun berikutnya (5 Februari 1928), Inyiak Canduang mensponsori pertemuan besar para ulama Minangkabau bermazhab Syafi'i di Canduang. Dalam pertemuan itu, lahirlah organisasi Persatuan Madrasah Tarbiyah Islamiyah, di singkat

${ }^{1}$ Guru MTsN Durian Tarung Padang dan Alumni Program Doktor IAIN Imam Bonjol Padang 
dengan PMTI, sebagai organisasi yang bertanggung jawab untuk membina, memperjuangkan, dan mengembangkan Madrasah-madrasah Tarbiyah Islamiyah yang ada. Pada pertemuan itu, beberapa ulama tersebut juga menyatakan melakukan perubahan terhadap surau yang ia pimpin menjadi MTI, seperti Syekh Muhammad Jamil Jaho mendirikan MTI Jaho, Syekh Abdul Wahid mendirikan MTI Tabek Gadang, dan sebagainya. Pada tahun-tahun selanjutnya, MTI pun tumbuh dan berkembang di berbagai daerah.

Pada tahun 1937, jumlah MTI diperkirakan tidak kurang dari 300 sekolah yang bertebaran di seluruh sumatera, sejak Aceh hingga Sumatera Timur, dari Minangkabau sampai ke Jambi, ke Kuantan dan Indragiri (Soearti No. 5, 1937: 11). Pada tahun 1939, dilaporkan dalam majalah Soearti (No. 20, 1939: 1-2) bahwa jumlah madrasah yang bergabung dalam MTI sebanyak 117. Hingga tahun 1939, Siradjuddin Abbas, seperti dikutip Sanusi Latief, menegaskan di antara MTI yang berdiri di luar Minangkabau adalah: MTI di Curup dan Fajar Sainam (Bengkulu), Pulau Sangkar Kerinci, Padang Guci (Manna, Bengkulu), Balambangan Palembang, Sri Bandung, Rantau Panjang Sekayu (Palembang), Baruga (Sulawesi Selatan) dan Larantuka Lamakera (Flores). Hingga kini, MTI masih tetap eksis di beberapa tempat, meskipun jumlahnya mengalami penurunan. Meskipun demikian alumni yang dihasilkan memiliki peran penting, baik di tingkat lokal maupun nasional dalam membina sikap keberagamaan umat.

Karena MTI lahir dan berkembang di Sumatera Barat, maka tradisi MTI pun tampaknya memiliki perbedaan dengan tradisi pesantren di daerah Jawa. Mengenai tradisi pesantren, telah dikaji oleh Zamakhsyari Dhofier dalam disertasinya "Tradisi Pesantren; Studi tentang Pandangan Hidup Kyai." Namun, tradisi MTI belum ditemukan kajian tentangnya.

\section{B. Tradisi Madrasah Tarbiyah Islamiyah}

Kata tradisi berasal dari bahasa Inggri, tradition, berarti tradisi (Hassan Shadily, 1980: 599). Dalam KBBI (2007: 1208), tradisi di artikan sebagai segala sesuatu-seperti kepercayaan, kebiasaan, ajaran, dan sebagainya-yang turun temurun dari nenek moyang yang masih dijalankan dalam masyarakat. Tradisi juga diartikan sebagai penilaian atau anggapan bahwa cara-cara yang telah ada merupakan yang paling baik dan benar (Abuddin Nata, 2012: 310).

22 | Tradisi Madrasah Tarbiyah Islamiyah 
Jadi, yang dimaksud dengan tradisi Madrasah Tarbiyah Islamiyah (MTI) dalam kajian ini adalah segala sesuatu yang dibiasakan, dipahami, dihayati dan dipraktikkan di MTI sebagai lembaga pendidikan Islam tradisional/kaum Tua yang lahir di Minangkabau, yaitu berupa nilai-nilai dan implementasinya dalam kehidupan sehari-hari sehingga membentuk kebudayaan dan peradaban yang membedakannya dengan tradisi yang terdapat pada lembaga pendidikan lainnya.

Sejauh ini, belum ditemukan kajian tentang tradisi MTI sebagai lembaga pendidikan Islam kaum Tua di Minangkabau yang eksis hingga saat ini. Literatur yang banyak membahas tradisi lembaga pendidikan Islam tradisional adalah "pesantren". Zamakhsyari Dhofier (1994: 44) menyebut, ada lima elemen dasar yang tidak bisa dipisahkan, yaitu pondok, masjid, santri, pengajaran kitab Islam klasik, dan kiai. Sedangkan Abuddin Nata (2012: 309-319) menyebutkan di antara tradisi pesantren adalah: 1) tradisi rihlah ilmiah, 2) tradisi menulis buku, 3) tradisi meneliti, 4) tradisi membaca kitab kuning, 5) tradisi berbahasa Arab, 6) tradisi mengamalkan thareqat, 7) tradisi menghafal, 8) tradisi berpolitik, dan 9) tradisi lainnya seperti tradisi poligami bagi kiai yang dilakukan dalam rangka menghasilkan keturunan yang dapat menjadi kiai lebih banyak; tradisi ziarah kubur, terutama kuburan para kiai thariqat yang karismatik; tradisi haulan, yakni mengirim doa tahunan kepada pimpinan pesantren yang sudah meninggal; tradisi silaturahmi dengan sesama rekan para santri.

Tradisi MTI, pada umumnya memiliki banyak persamaan dengan tradisi pesantren. Bahkan dalam perkembangan terakhir, MTI sendiri dikenal dan dikategorikan sebagai pondok pesantren. Meskipun demikian, terdapat pula beberapa perbedaan tradisi pesantren dengan tradisi MTI. Perbedaan itu lebih disebabkan oleh faktor sosio-kultural dimana pesantren tumbuh dan berkembang di tanah Jawa, sedangkan MTI awal pertumbuhannya di ranah Minang.

Berikut ini akan dikemukakan beberapa tradisi yang menonjol pada MTI, baik yang memiliki persamaan dengan tradisi pesantren secara umum maupun tradisi yang khas pada MTI itu sendiri.

1. Paham keagamaan: beri'tiqad Ahl al-Sunnah wa al-Jamā'ah dan bermazhab Syafi'i 
Sistem nilai yang berkembang di kalangan MTI memiliki persamaan dengan pesantren pada umumnya, yaitu berakar pada agama Islam itu sendiri. Hanya saja mereka menamakan sistem nilai yang dipakainya itu dengan ungkapan "Ahl al-Sunnah wa al-Jamā'ah" dalam persoalan aqidah (Nurchalish Madjid, 1997:31), yang mengacu pada ajaran-ajaran Imam Abu Hasan al-Asy'ari (w. 324 H) dan Imam Abu Mansur al-Maturidi (w. 333 H), (Alaiddin Koto, 1996: 78-82).

Meskipun paradigma keagamaan di bidang tauhid di kalangan Tarbiyah Islamiyah ini mengacu pada kalam al-Asy'ari, akan tetapi kitab-kitab yang dipelajari di MTI bukanlah karya dari alAsy'ari, seperti al-Ibānah. Akan tetapi kitab-kitab tauhid yang dikaji merupakan kitab yang disusun oleh ulama yang berpaham al-Asy'ariyah. Salah satu cirinya adalah kajian terhadap sifat dua puluh, rukun iman yang enam, dan sebagainya. Bahkan pendiri MTI Syekh Sulaiman ar-Rasuli sendiri menulis kitab tauhid untuk kelas pemula yang berjudul Aqwāl al-Mardhiyah yang isinya juga mengakaji tentang sifat dua puluh.

Di samping itu, dalam persoalan fiqh atau ibadah MTI menyatakan dirinya secara tegas bermazhab Syafi'i. Hal ini sangat beralasan mengingat Abu Hasan al-Asy'ary (w. $324 \mathrm{H}$ ) sendiri merupakan ulama yang bermazhab Syafi'i (Kholil Abu Fateh, 2012: 15 dan Siradjuddin Abbas, 2010: 25). Penegasan MTI sebagai lembaga pendidikan Islam yang mempertahankan mazhab Syafi'i ini tampak jelas pada ijazah santri yang lulus dari Madrasah Tarbiyah Islamiyah (MT) Candung dan di beberapa MTI lainnya, ditandatangani sendiri oleh Syekh Sulaiman arRasuli.

Dalam hal ini, MTI juga memiliki kesamaan dengan pesantren di Jawa. Hanya saja kaum santri di Jawa mewajibkan mengikuti salah satu dari sekurang-kurangnya empat imam mazhab fiqh: Maliki, Syafi'i, Hanafi dan Hambali. Tapi, umumnya mereka lebih menitikberatkan pada mazhab Imam Syafi'i sebagai mazhab yang dianut oleh masyarakat Indonesia pada umumnya (Rozikin Daman, 2001: 60). Akan tetapi tidak ada penekanan bahwa mazhab Syafi'i yang menjadi pegangan ketika berfatwa dan menetapkan hukum, sebagaimana yang dilakukan MTI.

Menurut Sirajuddin Abbas (2010: 221), pelajaran yang 24 | Tradisi Madrasah Tarbiyah Islamiyah 
tersimpul dalam mazhab Syafi'i itu sudah dipakai di Indonesia ini sejak beberapa ratus tahun yang lalu. Jika ditukar dengan pelajaran mazhab lain, bisa menimbulkan kekacauan sebab menukar apa yang telah biasa dipakai. Ia juga menegaskan bahwa memilih mazhab Imam Syafi'i bukan berarti menyalahkan tiga mazhab lainnya (Maliki, Hanafi, dan Hambali). Semuanya betul, tapi karena mazhab Imam Syafi'i itu sudah benar, maka apalah gunanya mengganti dengan yang betul lainnya?

Karena tradisi MTI dibangun berdasarkan mazhab Syafi'i dalam persoalan ibadah, maka praktik amalan ibadah yang dilakukan oleh santri juga mengacu pada mazhab ini. Demikian pula kitab-kitab yang diajarkan di MTI, umumnya kitab yang ditulis oleh ulama yang bermazhab Syafi'i, terutama kitab di bidang fiqh. Siradjuddin Abbas (2010: 182-186) menulis, paling tidak ada 97 kitab fiqh populer yang ditulis oleh ulama-ulama bermazhab Syafi'i, 20 di antaranya kitab yang ditulis oleh Imam Syafi'i sendiri. Di antara kitab-kitab tersebut, terdapat lima kitab yang biasanya diajarkan di MTI, yaitu: 1) Matn al-Ghāyah wa al-Taqrīb, karangan Syekh Syihab al-Dunya wa al-Din, Ahmad bin al-Husain bin Ahmad al-Ashfahāny yang terkenal dengan galar Abu Syujā'; 2) Fath al-Qarīb al-Mujīb Syarh Matn Taqrīb, karangan Syekh Muhammad bin Qāsim al-Ghazi; 3) Fath alMu'in, karangan Imam Zakaria al-Malibari; 4) I'ānah al-Thālibīn, karangan Sayyid Abi Bakr Syatha al-Masyhūr Sayyid al-Bakri; dan 5) al-Mahalli, karangan Imam Jalāl al-Dīn al-Mahalli.

Menarik pula untuk dicermati bahwa kitab fiqh yang ditulis oleh Imam Syafi'i yang terkenal, seperti al-Üm dan al-Risālah tidak dipelajari oleh santri-santri MTI di kelas formal. Namun kitab yang dipelajari adalah kitab-kitab yang ditulis oleh ulama-ulama yang bermazhab Syafi'i yang lahir beberapa abad berikutnya, seperti Syekh Ahmad bin al-Husain bin Ahmad al-Ashfahāny pengarang kitab Matn al-Ghāyah wa al-Taqrīb adalah ulama abad ke IX H (w. 892 H); Sayyid Abi Bakr Syatha al-Masyhūr Sayyid al-Bakri, pengarang I'ānah al-Thālibīn, adalah ulama abad ke XIV H. Kitab ini selesai ditulis tahun 1300 $\mathrm{H}$ yang merupakan syarh dari kitab Fath al-Mu'in, sedangkan Imam Jalāl al-Dīn al-Mahalli pengarang kitab al-Mahalli dan juga tafsir Jalālain — bersama Jalāl al-Dīn al-Suyuthi-adalah ulama abad ke IX H, lahir tahun $769 \mathrm{H}$ dan wafat $835 \mathrm{H}$. 
Tidak dipelajarinya kitab karangan Imam Syafi'i, seperti al$\bar{U} m$ dan al-Risālah bukanlah meninggalkan sumber primer dari kajian fiqh itu sendiri. Akan tetapi untuk memahami karya Imam Syafi'i itu sendiri butuh penjelasan dan uraian yang lebih lugas, rinci dan mudah dimengerti. Penjelasan dan uraian itulah yang dilakukan oleh ulama-ulama sesudahnya yang tetap merujuk pada karya-karya Imam Syafi'i itu sendiri. Inilah menjadi salah satu alasan mengapa kitab-kitab ulama bermazhab Syafi'i di atas yang dijadikan kitab referensi utama di lingkungan MTI, termasuk pesantren pada umumnya. Namun kondisi ini juga menuai kritik, kenapa MTI tidak langsung mempelajari kitabkitab yang ditulis oleh Imam Syaf'i, paling tidak untuk santri kelas tinggi? (Alaiddin Koto, 1996: 111)

Perlu pula ditekankan bahwa dalam hal aqidah, mereka berkeyakinan bahwa ajaran Ahl al-Sunnah wa al-Jamā'ah adalah yang terbenar, selain dari paham itu dianggap keliru dan harus ditentang terus-menerus. Sedangkan di bidang fiqh, mereka tidak mengatakan jika mazhab Syafi'i yang paling benar, sehingga mereka juga mengakui keabsahan tiga mazhab lainnya. Hanya saja kepada para santri ditanamkan kesan bahwa Imam Syaf'i lebih ihtiyath dalam istimbat hukum. Kecuali itu, Imam Syafi'i juga pemikir yang mampu mengompromi dan akhirnya menemukan jalan tengah antara dua metode berpikir yang ada di masanya (rasional dan tradisional). Karena alasan itulah sangat beralasan jika mazhab Syafi'i diikuti secara intens, tanpa harus menoleh kepada imam atau mazhab-mazhab lainnya. Kesetiaan kepada paham ahl al-Sunnah wa al-Jama 'ah dan mazhab Syafi'i ini pun menjadi tradisi di kalangan MTI dimana setiap lulusannya "dibai'at" agar mempertahankan dan mengamalkan paham tersebut, sebagaimana yang tertulis di ijazah. Menurut Alaiddin Koto (1996: 112-113), kekukuhan mereka dalam bersikap dan mempertahankan paham keagamaannya menimbulkan suara sumbang pihak luar terhadap mereka. Mereka dianggap sebagai kaum sempit, eksklusif, mandek dalam berpikir, elergi terhadap pembaharuan dan modernisasi. Mereka dianggap kaum muqallid mazhab yang senantiasa taqlid kepada mazhab tertentu.

Namun pandangan di atas tidaklah sepenuhnya benar. Meskipun para santri ditanamkan agar mempertahankan mazhab Syafi'i sebagaimana yang terdapat dalam ijazah di atas, akan 26 | Tradisi Madrasah Tarbiyah Islamiyah 
tetapi mereka juga diperkenalkan pemikiran dari mazhab-mazhab lain. Di MTI Canduang, misalnya, untuk santri kelas VI dan VII diajarkan kitab Al-Asybāh wa al-Nazhā'ir fi al-Furu' 'yang berisi tentang pandangan empat mazhab terkait fiqh. Bahkan untuk santri kelas VII diajarkan pula kitab Bidāyah al-Mujtahid karya Ibn Rusyd (520 H-595 H) yang memuat pandangan empat mazhab tentang persoalan-persoalan yang menyangkut hukum/ fiqh. Karena itu pula, di kalangan santri MTI Canduang, menyebut kitab ini dengan sebutan "Madzahib". Hal ini memberi kesan bahwa Syekh Sulaiman ar-Rasuli tidak menginginkan santrinya berpikiran sempit seperti anggapan di atas, tetapi mereka tetap diberi ruang untuk memahami perbedaan-perbedaan pandangan dari para fuqahā'. Apalagi Ibn Rusyd sendiri adalah ulama yang lebih cenderung pada mazhab Maliki. Karena itu, santri yang menyelesaikan studinya di MTI ini (alumni), umumnya bersifat lebih terbuka, tidak fanatik secara berlebihan, dan cenderung tidak mudah mengkafirkan orang lain, terutama dalam persoalanpersoalan fiqh.

\section{Tradisi Kitab Kuning}

Seperti pesantren pada umumnya, Madrasah Tarbiyah Islamiyah juga menerapkan kitab kuning, sebagai media dan sumber belajar dalam memahami ilmu-ilmu keislaman (tafaqquh fi al-dìn). Namun kitab kuning yang dipelajari di MTI pada umumnya berbahasa Arab, bukan berbahasa Arab Melayu atau berbahasa lokal. Kitab kuning dalam artian berbahasa Melayu atau Minangkabau dengan menggunakan aksara Arab, memang ditemukan seperti beberapa kitab yang ditulis oleh Syekh Sulaiman ar-Rasuli, akan tetapi tidak menjadi kitab yang dipelajari oleh santri di MTI.

Di samping itu, kitab yang dipelajari umumnya tergolong pada kitab yang ditulis sebelum abad 19 (al-kutub al-qādimah) (Umiarso dan Nur Zazin, 2011:36). Meskipun demikian, terdapat pula kitab yang ditulis oleh pendiri MTI itu sendiri, seperti kitab tauhid karangan Syekh Sulaiman ar-Rasuli berjudul al-Aqwāl alMardhiyyah yang umumnya dipelajari oleh santri MTI di tingkat pemula dan kitab akhlak yang dikarang oleh Syekh Muhammad Jamil Jaho berjudul Tadzkirah al-Qulüb yang dipelajari oleh santri 
MTI Jaho, khususnya, di kelas VI. Namun kedua karya ini tetap menggunakan bahasa Arab. Setelah MTI mengikuti program pemerintah berupa MTs dan MA, maka kitab-kitab berbahasa Arab yang ditulis pasca abad ke-19 mulai ditemukan, khususnya untuk santri yang mengikuti program studi Ilmu Agama Islam (IAI) di tingkat Aliyah. Namun kitab kuning dalam pengertian kitab klasik tetap menjadi ciri utama dari MTI. Karena kitab ini menggunakan bahasa Arab, maka santri MTI umumnya bisa membaca, mengartikan dan memahami teks berbahasa Arab. Dalam hal ini, penguasaan mereka terhadap ilmu alat untuk memahami seluk beluk bahasa Arab tersebut menjadi sangat penting.

Kelemahannya, mereka kurang aktif dalam berbicara bahasa Arab sehari-hari karena kurang dipraktikkan ketika berkomunikasi, baik di lingkungan madrasah maupun di luar. Guru sendiri juga tidak menggunakan bahasa Arab sebagai bahasa pengantar ketika menjelaskan materi. Mereka bisa mengkritisibahkan menyalahkan - orang yang berbahasa Arab aktif dari segi tata bahasanya jika ada yang keliru, namun mereka sendiri kurang aktif dan kurang lancar jika diminta untuk berkomunikasi langsung dengan menggunakan bahasa Arab tersebut.

3. Tradisi Metode Pembelajaran

\section{a. Kaji Batungkuihan, belajar dengan guru tuo}

Dalam tradisi MTI, tidak dikenal penggunaan istilah sorogan dan bandongan atau weton, seperti yang berkembang di pesantren tanah Jawa (Dhofier, 1988: 20). Akan tetapi, cara yang digunakan dalam metode itu juga diterapkan di MTI, namun tidak menggunakan istilah atau nama tersebut. Metode sorogan, misalnya, diterapkan di MTI dalam bentuk pembelajaran santri dengan guru tuo. Dalam hal ini, santri berkunjung ke rumah guru, biasanya di malam hari, membawa kitab yang akan dipelajari esok hari untuk dibahas bersama guru tersebut sehingga keesokan harinya santri itu telah memiliki bekal untuk membaca, memahami, bahkan berdebat dengan teman-teman lainnya terkait cara membaca dan pemahaman dari teks yang akan dipelajari dari kitab tersebut. Guru yang didatangi itu bisa santri senior, guru pembina asrama, atau urang siak yang pernah belajar di

28 | Tradisi Madrasah Tarbiyah Islamiyah 
pesantren/madrasah yang berada di sekitar tempat tinggal santri.

Proses pembelajaran dengan metode sorogan ini dinilai efektif karena pembelajaran lebih berorientasi pada individual learning process. Pembelajaran ini dikenal juga dengan kaji "batungkuihan" atau "babungkuihan" yang arti secara bahasa adalah "dibungkuskan", yaitu guru memberi bekal pada santri dalam memahami kitab yang dipelajari santri bersangkutan keesokan harinya sehingga bisa menguasai pelajaran, bahkan berdebat dengan santri lain jika ada perbedaan antara apa yang ia peroleh dari guru tuo dengan pembahasan guru dan santri lainnya di dalam kelas. Alumni MTI Canduang, Buya Syamsul Bahri Khatib (wawancara, 1 April 2013) menyebut guru tuo atau santri senior ini dengan istilah "memberi umpan" kepada santri yunior untuk bekal belajar keesokan harinya. Namun sistem pembelajaran kaji babungkuihan ini tidak semata-mata guru yang aktif, tetapi guru juga memberi kesempatan kepada santri untuk membaca kitab kuning atau mengemukakan pendapatnya terlebih dahulu, kemudian barulah guru tuo meluruskannya.

\section{b. Metode hafalan}

Metode hafalan masih menjadi salah satu metode yang tetap dipertahankan di MTI, sebagaimana yang juga dilakukan di pesantren pada umumnya. Metode ini sangat diperlukan, khususnya dalam mempelajari nahwu dan sharf, termasuk dalam bentuk nazham seperti kitab Alfiyah. Hal-hal yang bersifat undang-undang (qawa'id) harus dihafal, apalagi ketika mempelajari kitab kuning, biasanya santri diminta untuk mengi'rab setiap kata yang dibaca. Tanpa hafalan yang memadai terhadap qawa'id dari tata bahasa Arab tersebut, mustahil santri dapat melakukannya. Begitu juga dalam mempelajari ushul fiqh, santri diwajibkan menghafal kaidah-kaidah tertentu, serta dalam mempelajari hadis, beberapa di antaranya harus dihafal oleh santri berdasarkan bimbingan dan perintah guru.

Menurut Husein Muhammad (1999: 281), metode hafalan tampaknya telah menjadi ciri dan cap yang melekat pada sistem pendidikan tradisional, termasuk pesantren. Ada sebuah argumen yang diajukan untuk mempertahankan metode ini, yaitu "orangorang yang hafal adalah argumen atas mereka yang tidak hafal" 
(al-hiffāzh hujjah 'alā man lā yahfazh). Namun menurutnya, ketika konsep keilmuan lebih menekankan rasionalitas seperti yang menjadi dasar sistem pendidikan modern, maka metode hafalan kurang dipandang penting. Sebaliknya, yang penting adalah kreativitas dan kemampuan mengembangkan pengetahuan yang dimiliki. Dalam pendidikan modern, ilmu selalu mengandung kemungkinan-kemungkinan untuk digugat dan diterobos sehingga akal sebagai landasan utamanya seringkali menghasilkan dinamika-dinamika spekulatif.

Pendapat di atas memang benar adanya. Ketika pendidikan modern mulai menyentuh pesantren, termasuk MTI, maka secara perlahan metode hafalan mulai berkurang. Metode hafalan memang tetap dipertahankan hingga saat ini, terutama yang terkait dengan qawa'id dalam ilmu nahwu, sharf, ushul fiqh, dan beberapa hadits, akan tetapi para santri kurang memiliki hafalan yang kuat terhadap apa-apa yang telah diperintahkan guru untuk dihafal. Tampaknya, pola pembelajaran modern pada mata pelajaran lain yang tidak mementingkan lagi hafalan turut menjadi salah satu penyebab dari kondisi itu. Akibatnya, kemampuan santri dalam membaca kitab kuning pun cenderung menurun kualitasnya.

\section{c. Muthāla'ah}

Kata muthāla'ah (bentuk mashdar dari thāla'a-yuthāli'umuthāla'ah) artinya pembacaan (qirā'ah) atau penelaahan (A.W. Munawwir, 1997: 861). Metode muthāla'ah yang dimaksud dalam tradisi MTI adalah santri membaca atau menelaah pelajaran, biasanya kitab kuning, baik yang telah dipelajari maupun yang belum dipelajari. Ketika santri bersangkutan tidak memahami bacaan atau maksud dari apa yang telah ia baca, maka santri tersebut bisa bertanya dengan sesama temannya sehingga mereka saling menelaah kitab tersebut. Atau santri tersebut langsung menghadap kepada guru tuo untuk menanyakan masalah yang ia temukan, baik setelah penelaahan yang belum tuntas bersama teman-temannya atau langsung menghadap guru tanpa menelaah terlebih dahulu dengan teman-temannya.

Bagi santri yang memiliki kecerdasan lebih, ada pula yang menelaah dengan sendirinya kitab-kitab yang akan dipelajari

30 | Tradisi Madrasah Tarbiyah Islamiyah 
tanpa banyak persoalan yang ia temukan untuk diajukan kepada guru tuo. Bahkan santri yang cerdas dan bersungguh-sungguh, bisa menamatkan kitab tertentu - terutama kitab-kitab besardengan menelaah secara individual, sementara kitab tersebut tidak dipelajari hingga selesai karena keterbatasan waktu. Di sinilah pentingnya metode ini dalam tradisi MTI sehingga melahirkan ulama-ulama yang handal dan berpengaruh. Menurut Husein Muhammad, metode muthāla'ah ini sangat memungkinkan untuk dilakukan oleh santri jika dalam pembelajaran di kelas lebih mengedepankan metode diskusi (munāzharah).

Menariknya, tidak saja santri yang melakukan metode muthāla'ah ini. Guru yang akan mengajar di kelas pun, biasanya menelaah terlebih dahulu materi dari kitab kuning yang akan diajarkannya untuk esok harinya. Hal ini dilakukan sebagai bentuk persiapan jika keesokan harinya ada pertanyaanpertanyaan kritis dari santri-santrinya. Apalagi santri itu sendiri telah dibekali oleh guru tuo, sebagaimana yang disebut di atas sebagai kaji babungkuihan. Lebih-lebih bagi guru yang masih relatif muda atau baru, maka ia akan menelaah lebih serius setiap materi yang akan ia ajarkan (Syafrizal, Alumni dan Guru MTI Canduang, wawancara, 9 Feb. 2013).

\section{d. Munāzharah}

Secara etimologi, kata munāzharah (bentuk mashdar dari nāzhara-yanzhiru-munāzharah) mengandung arti perdebatan (mujādalah), persaingan/perlombaan (munāfasah), perbantahan/ diskusi (munāqasyah), pemeriksaan/pengontrolan (murāqabah), atau perbandingan (A.W. Munawwir, 1997: 1435, Atabik Ali dan Ahmad Zuhdi Muhdlor, 1998: 1827 dan Mahmud Yunus, 1990: 457). Kata munāzharah juga mengandung makna musyārakah sehingga ia bermakna saling berdiskusi atau saling memperhatikan. Metode ini sebenarnya telah digunakan dalam sistem pembelajaran halaqah di surau sebelum abad XX seperti yang dikemukakan oleh Sanusi Latief (1988: 75). Menurutnya, dalam metode munāzharah ini, salah seorang santri ditunjuk untuk membaca teks suatu kitab dalam masalah tertentu, lalu ia menjelaskan isi dari teks tersebut. Kemudian ia harus menjawab pertanyaan atau sanggahan dari santri-santri lainnya, dengan 
memberikan dalil-dalil atau pun kaedah-kaedah untuk menunjang pendapatnya. Apabila terdapat jalan buntu atau pun kekeliruan pemahaman dalam perdebatan ini, maka Syekh atau guru tampil sebagai hakim untuk meluruskan pengertian yang keliru dari pada pelajar. Dengan demikian, terjadi dinamika di antara santri dalam mempelajari ktiab kuning sehingga proses pembelajaran yang dikedepankan adalah pembelajaran aktif (active learning). Setelah itu, barulah guru memberi klarifikasi dan konfirmasi terhadap persoalan yang dibicarakan.

Metode munāzharah ini kemudian bertahan dan menjadi tradisi MTI. Kondisi ini menunjukkan bahwa MTI sebagai bentuk perubahan dari surau tidak sertamerta meninggalkan seluruh sistem pembelajaran yang ada di surau tersebut. Bertahannya metode ini didukung pula oleh pembelajaran dengan guru tuo, seperti yang dikemukakan di atas. Jika santri telah belajar dengan guru tuo di malam hari, maka proses pembelajaran di dalam kelas lebih aktif dan diselingi dengan perdebatan. Dalam konteks ini, bisa saja seorang santri berbeda pendapat dengan gurunya di dalam kelas karena perbedaan pemahaman yang diajarkan oleh guru tuo-nya. Jika guru bersangkutan memiliki kemampuan yang baik, maka guru tersebut bisa "menundukkan" pemahaman santri tersebut sebagaimana yang dipahami oleh guru itu.

Meskipun begitu, perbedaan pendapat itu tidak sampai menimbulkan sikap yang kurang santun atau sikap melawan kepada guru. Di sinilah salah satu keunikan pembelajaran yang dibangun di MTI, kritis, berdebat, bahkan bisa berbeda pendapat, tetapi tetap santun dan menghormati gurunya.

Jadi, perbedaan yang paling menonjol antara metode pembelajaran yang dikembangkan di pesantren dengan MTI adalah daya kritis santri MTI. Di pesantren yang ada di Jawa, secara sosio-kultural mereka sangat fanatik dan menghormati guru-guru mereka. Mereka senantiasa yakin bahwa gurunya tidak mengajarkan hal-hal yang salah. Mereka (santri) percaya bahwa apa-apa yang diajarkan kiai adalah benar, tidak perlu diperdebatkan, tetapi perlu diamalkan (Mastuhu, 1994: 61). Berbeda halnya di MTI, santri-santrinya diberi kesempatan untuk bertanya bahkan berdebat dengan teman, termasuk guru yang sedang mengajar, tetapi tetap menggunakan cara dan bahasa

32 | Tradisi Madrasah Tarbiyah Islamiyah 
yang santun.

Namun tradisi belajar aktif yang diselingi dengan perdebatan ini mulai menurun kualitasnya akhir-akhir ini. Beberapa orang guru justru menerapkan pembelajaran seperti metode wetonan atau bandongan yang cenderung santri pasif dimana guru terlebih dahulu membaca kitab kuning yang ia ajarkan, sementara santri hanya mendengarkan, setelah itu beberapa orang santri diminta untuk membaca ulang. Salah satu faktor penyebab yang paling menonjol adalah sistem belajar dengan guru tuo yang mulai sulit ditemukan. Kalau pun ada MTI yang masih menerapkan belajar dengan guru tuo umumnya dilaksanakan di asrama dan santri yang dibina oleh seorang guru tuo pun relatif lebih banyak. Lain lagi dengan kemampuan guru tuo itu sendiri yang penguasaannya terhadap materi cenderung masih rendah. Akibatnya, dalam proses pembelajaran di kelas, santri yang mendebat temannya, apalagi gurunya, sudah mulai jarang ditemukan.

Selain itu, ketika menerjemahkan kitab, digunakan pula bahasa daerah, yaitu bahasa Minangkabau. Terdapat pula bahasa khusus yang biasa digunakan pada kedudukan kalimat tertentu. Misalnya, untuk mengartikan kata yang berkedudukan sebagai mubtadda' atau pokok kalimat, mendahulukan kata baramulo. Sedangkan mengartikan kata berkedudukan sebagai khabar atau predikat dalam kalimat mendahulukan kata baalah baramulo, dan seterusnya.

\section{e. Mudzākarah}

Istilah muthāla'ah dan munāzharah memang tidak populer di kalangan santri MTI, akan tetapi apa yang dimaksud dari kedua metode tersebut, seperti yang dijelaskan di atas, memang dilaksanakan di internal MTI itu sendiri. Berbeda halnya dengan metode mudzākarah, istilah ini demikian populer di kalangan santri dan guru MTI. Kata mudzākarah (bentuk mashdar dari kata $d z \bar{a} k a r a-y u d z \bar{a} k i r u-m u d z a \overline{k a r a h}$ ), berarti konsultasi, diskusi, permusyawaratan (mudāwalah, mubāhatsah), mempelajari (study), saling ingat-mengingatkan, atau belajar bersama (A.W. Munawwir, 1997: 449, Atabik Ali, 1998: 927 dan Mahmud Yunus, 1990: 134). Sedangkan pengertian terminologi, Ismail dan Abdul Mukti, seperti yang dikutip Umiarso dan Nur Zazin, 
menyebutkan bahwa metode mudzākarah adalah pertemuan ilmiah secara khusus membahas persoalan agama pada umumnya yang berfungsi melatih santri untuk memecahkan masalah dengan menggunakan suatu rujukan kitab-kitab kuning yang tersedia. Bahkan dalam metode ini, santri secara akselerasi akan membangun mental yang kuat dalam mengemukakan pendapat secara demokratis dan juga melatih santri untuk menghargai pendapat dari orang lain (Umiarso dan Nur Zazin, 2011: 39).

Pengertian mudzākarah di atas juga berlaku di MTI dan menjadi salah satu tradisi yang dibangun oleh guru bersama santri. Biasanya, santri-santri yang hadir dan lebih banyak perperan dalam forum ini adalah santri senior atau santri Aliyah yang dilakukan pada waktu-waktu tertentu, misalnya sekali dalam seminggu. Pelaksanaannya ada yang seperti debat dimana para santri dikelompokkan menjadi dua kelompok dan diberi suatu permasalahan. Misalnya kelompok pertama mengakaji dari pemahaman mazhab Syafi'i, sedangkan kelompok lainnya dari sisi mazhab Hanafi. Masing-masing kelompok memberikan argumentasinya dengan merujuk pada kitab kuning yang telah mereka pahami sebelumnya. Sementara Buya atau guru lebih bertindak sebagai moderator dan pada pertemuan akhir barulah guru tersebut meluruskan atau menyimpulkan dari debat tersebut. Model seperti ini sering dilakukan di MTI Jaho (Yasmadi, alumni MTI Jaho, Wawancara, Padang: 5 Agustus 2012).

Metode mudzākarah bisa juga dipahami pertemuan antara santri tanpa mengkondisikan dua kelompok besar yang bertentangan pemahamannya.Mudzākarahbisajuga dilaksanakan dalam bentuk diskusi ilmiah dimana audiens diberikan suatu permasalahan lalu mengemukakan pendapat masing-masing dengan argumentatif dan pemahamannya biasanya merujuk pada kitab-kitab kuning yang telah mereka pelajari. Tidak jarang terjadi perbedaan pendapat di antara mereka sehingga terjadilah perdebatan yang menarik. Sedangkan guru bertindak sebagai "moderator" dan di akhir pertemuan meluruskan permasalahan yang diperdebatkan tersebut. Tradisi ini tidak saja terjadi antara santri, tetapi juga biasanya dilakukan di antara guru-guru, terutama guru-guru muda sebagai peserta aktif sedangkan yang menjadi penengah adalah guru senior.

34 | Tradisi Madrasah Tarbiyah Islamiyah 


\section{Pendidik}

Dalam tradisi Minangkabau, ulama memiliki peranan yang sangat penting. Sebab dalam kepemimpinan di Minangkabau, secara adat disebut ninik mamak pemangku adat, yang terbagi ke dalam urang ampek jinih dan keempatnya juga disebut sebagai perangkat nagari, yaitu penghulu, manti, malin, dan dubalang. Prinsip kepemimpinan ulama atau malin/mu'allim ini adalah kato malin kato hakikat, tagak di pintu kitab; fungsinya: suluah bendang dalam nagari, nan tau sah jo batal, tau halal jo haram, melaksanakan suruah, menghentikan semua larangan Allah dan Rasul; kerjanya memberikan penyuluhan agama Islam, mengurus nikah, talak, rukuk, kelahiran, kematian, zakat, infak, sedekah, dan lain-lain; prosedur kepemimpinannya mengaji sepanjang kitab, kitab datang dari Allah, sunnah datang dari Rasul, satitiak bapantang hilang sabarih bapantang lupo; pada hakikatnya ulama ini tegak di pintu Syarak (agama Islam) (M. Sayuti, 2005: 97-99 dan 2000: 54; Amir M.S. 2006: 22).

Selain urang nan ampek jinih, dikenal pula jinih nan ampek yang juga berfungsi sebagai pemimpin, tetapi hanya dalam persoalan syarak, yaitu: Imam, Khatib, Bilal, dan Kadi. Jinih nan ampek ini dituntut keteladanannya di tengah-tengah masyarakat dalam membimbing sikap keberagamaan umat. Selain itu, dikenal pula istilah urang tigo jinih, atau "tungku nan tigo sajarangan, tali nan tigo sapilin", yaitu ninik mamak, alim ulama dan cadiak pandai. Prinsip kepemimpinannya adalah ninik mamak tagak di pintu adat, alim ulama tagak di pintu syarak (agama Islam), dan cadiak pandai tagak di pintu ilmu (M. Sayuti, 2005: 99 dan 2000: 54).

Mengacu pada konsep kepemimpinan dalam kultur masyarakat Minangkabau, maka mustahil ulama diabaikan. Dalam tradisi MTI, ulama tersebut bertindak sebagai guru sekaligus da'i atau muballigh. Umumnya mereka tidak saja menjalankan tugasnya sebagai pendidik di lingkungan madrasah, tetapi juga menjalankan peran keulamaannya sebagai salah satu unsur penting dalam bernagari atau bermasyarakat.

Peran strategis ulama di MTI memiliki kesamaan dengan kiai dalam tradisi pesantren. Dalam tradisi pesantren, kiai menjadi 
salah satu unsur terpenting. Dalam diri kiai, terdapat beberapa kemampuan, di antaranya sebagai perancang (arsitektur), pendiri dan pengembang (developer), dan sekaligus sebagai seorang pemimpin dan pengelola (leader dan manager) pesantren (Mardhiyah, 2012: 55). Tidak saja memimpin dan mengelola pesantren, kiai juga berperan sebagai pembina dan pendidik umat serta menjadi pemimpin masyarakat. Namun di MTI, tidak dikenal istilah kiai. Akan tetapi peran kiai seperti yang digambarkan di atas juga dimiliki oleh MTI dan kedudukannya sangat penting. Hanya saja penamaannya bukan kiai, melainkan Syekh, Buya, atau Ustadz.

Zamakhsyari Dhofier mengemukakan kebanyakan sarjana sependapat bahwa dalam konsep organisme kenegaraan orang Jawa, raja dianggap sebagai simbol dari pancaran mikrokosmos, atau negara. Dalam pikiran orang Jawa kosmos dibagi dua, yaitu mikrokosmos (dunia manusia, dunia nyata) dan makrokosmos (alam gaib), dan raja dianggap sebagai penghubung antara kedua kosmos tersebut. Pada masa kerajaan Hindu, raja bahkan dianggap sebagai manifestasi ketuhanan dalam kehidupan mikrokosmos tersebut. Setelah Islam masuk, terjadi perubahan dalam pandangan tentang siapa yang kemudian dianggap sebagai wakil atau simbol dari kekuatan makrokosmos. Meskipun Islam tidak menempatkan pemimpin setinggi raja dalam konsepsi kerajaan Majapahit, misalnya, akan tetapi Islam juga mengakui bahwa ada nabi-nabi yang diberi keistimewaan sebagai utusanNya dan para ulama adalah pewarisnya (Dhofier, 1988: 58). Dari pemahaman seperti itu, maka bagi masyarakat Jawa, posisi ulama atau kiai sangat tinggi. Tidak jarang di antara mereka menganggap kiai sebagai simbol atau wakil dari makrokosmos, atau penghubung antara dua kosmos tersebut, sebagaimana pandangan awal mereka terhadap raja. Maka kiai pun sangat dihormati dan cenderung dikultuskan sebab dipandang sebagai orang suci, pewaris para nabi. Ronald (2004: 85) menyebutkan bahwa sering kali kiai dipandang sebagai "raja kecil". Santri memperlakukan kiai dengan penuh penghormatan, tidak berani menatap langsung pada saat bicara dengan kiai. Saat kiai lewat santri harus memberinya jalan, bahkan beberapa santri menundukkan kepala. Mereka yakin bahwa kiainya selalu mengajarkan hal-hal yang benar, dan mereka tidak percaya

36 | Tradisi Madrasah Tarbiyah Islamiyah 
kalau kiai dapat berbuat salah atau keliru sehingga ajaran yang disampaikannya diterima sebagai kebenaran absolut (Mastuhu, 1994: 58). Maka pihak pesantren sering kali memandang ilmu sebagai tidak identik dengan kemampuan berpikir metodologis, tetapi dipandang sebagai "berkah" yang dapat datang dengan sendirinya melalui pengabdian kepada kiai; terutama pengetahuan agama secara keseluruhan diangap sudah mapan kebenarannya sehingga tidak perlu dipertanyakan lagi (Mastuhu, 1994: 65). Akibatnya daya kritis santri cenderung kurang berkembang jika berhadapan dengan kiainya.

Sebaliknya para kiai sendiri beranggapan pula bahwa suatu pesantren pada dasarnya sama dengan sebuah kerajaan kecil di mana kiai merupakan sumber kekuasaan dan kewenangan yang absolut (Dhofier, 1988: 58). Akhirnya, kepemimpinan kiai berkembang menjadi apa yang disebut oleh Sidney Jones, seperti dikutip oleh Mardiyah (2012: 57), sebagai sebuah hubungan patron client yang sangat erat, di mana otoritas seorang kiai besar diterima di kawasan seluas provinsi, baik oleh pejabat pemerintah, pemimpin publik maupun kaum hartawan.

Berbeda halnya kultur masyarakat Minangkabau. Di daerah ini, sistem kepemimpinannya bersifat demokratis berdasarkan "kebenaran". Dalam hal ini dikenal gurindam adat yang mengatakan: "Kamanakan barajo ka mamak, mamak barajo ka panghulu, panghulu barajo ka mupakaik, mupakaik barajo ka nan bana, nan bana badiri sandirinyo." Adapun yang dimaksud dengan "kebenaran" itu adalah al-haq yang diturunkan oleh Allah SWT (Qs. Ali Imran/3: 60) yang dapat dipedomani pada Kitabullah, yakni al-Qur'an yang diiringi dengan Sunnah Rasulullah (Hadis). Inilah yang kemudian dirumuskan dalam falsafah "Adat Basandi Syarak, Syarak Basandi Kitabullah" atau sering disingkat dengan ABS-SBK (Musyair Zainuddin, 2008: 115). Jadi konsep kepemimpinan di Minangkabau itu bersifat "abstrak" dimana kebenaran sebagai pedoman tertinggi, yaitu perintah Allah SWT. Sedangkan kepemimpinan di Jawa lebih bersifat simbolik yang diakui sebagai manusia suci sehingga pemimpin, terutama kiai sebagai pemimpin spiritual, cenderung dipatuhi dan dikultuskan.

Sementara dalam gurindam adat di atas tampak jelas bahwa 
kemanakan mematuhi mamak selagi mamak itu teguh pada kebenaran. Begitu juga penghulu akan ditaati oleh mamak dan kemanakannya selagi penghulu tersebut berpegang teguh pada kebenaran. Karena itu, dikenal pula pepatah: Raja adil, raja disambah; raja zhalim, raja disanggah.

Konsep kepemimpinan seperti ini membuat kedudukan ulama atau pimpinan MTI/pesantren di Minangkabau akan senantiasa dipatuhi selama ulama tersebut berpegang teguh pada kebenaran. Sebagai manusia biasa, memungkinkan pendapatnya keliru, jika itu terjadi maka murid-muridnya bisa membantah dan mengemukakan pendapat yang berbeda. Pendeknya, ulama atau buya atau guru di MTI tidak selamanya dianggap benar tanpa cacat atau kesalahan, karena itu tidaklah heran jika murid-murid di MTI "berani" menyanggah pendapat gurunya jika dinilai apa yang disampaikan gurunya keliru.

Sebaliknya, guru sendiri tidaklah merasa direndahkan jika pendapatnya dipertanyakan atau malah disanggah oleh muridmuridnya. Malah ada kecenderungan mereka mengharapkan terjadinya dinamika pembelajaran yang mengedepankan pemikiran kritis dari murid-muridnya dan merasa kecewa ketika melihat murid-muridnya hanya diam tanpa daya kritis. Sebaliknya, ketika guru tidak mampu menjawab pertanyaan atau sanggahan yang disampaikan oleh murid, tanpa rasa kesal, mereka pun akan berjanji kepada murid-muridnya untuk mencari dan menemukan jawaban atas persoalan tersebut keesokan atau beberapa hari berikutnya. Di sinilah tampak demokratisasi pembelajaran di lingkungan MTI.

Pola hubungan antara guru dengan murid ini juga diungkapkan dalam pepatah yang demikian populer di kalangan MTI, yaitu: Cadiak guru dek ma-aja, cadiak murid dek batanyo, (cerdasnya guru karena mengajar, cerdasnya murid karena bertanya), (Buya Alimi, alumni MTI Buya Kanis Tengku Tuah, Tanyuah Simpang Batu Hampar, Wawancara, Padang: 7 Maret 2012). Pepatah ini mengisyaratkan seorang guru itu akan cerdas jika ia mengajarkan ilmunya, sebaliknya seorang murid akan menjadi cerdas jika berani bertanya. Konsekuensinya, seorang guru yang mengajar akan mendorong muridnya untuk berani bertanya, karena setiap guru menginginkan murid-muridnya menjadi cerdas pula. Selain

38 | Tradisi Madrasah Tarbiyah Islamiyah 
itu, dikenal pula pepatah: malawan guru jo kajinyo (melawan guru dengan kajinya). Seorang murid "melawan" kepada guru dalam persoalan memahami suatu ilmu dimana seorang murid dapat bertanya, bahkan menyanggah gurunya dengan argumen yang tepat berdasarkan ilmu pula. Jadi tidak ada unsur kebencian.

Meskipun murid "berani" berdebat atau menyanggah pendapat gurunya, akan tetapi mereka tetap santun dan hormat kepada gurunya. Bahkan kata-kata yang digunakan pun tetap mengedepankan tutur kata yang sopan. Hal ini juga dipengaruhi oleh kultur Minangkabau sendiri yang mengenal adanya adab berbicara dan berperilaku yang dikenal dengan jalan nan ampek, yaitu jalan mandaki, jalan manurun, jalan mandata, dan jalan malereng. Dalam hubungan murid kepada guru, maka yang digunakan adalah jalan mandaki, sehingga seorang murid dituntut untuk menghormati dan bertutur kata yang sopan terhadap gurunya. Sebaliknya, hubungan guru kepada murid adalah jalan manurun, dengan tetap mengedepankan kasih sayang. Dalam hal ini, dikenal pula pepatah Minang: nan tuo dihormati, samo gadang ajak bakawan, nan ketek disayangi (yang tua dihormati, seusia ajak berteman, yang kecil disayangi) (Amir M.S. 2006: 4).

5. Murid

Dalam tradisi MTI di era awal, peserta didik lebih dikenal dengan sebutan "murid". Sebutan murid sebenarnya lebih sering digunakan dalam isitilah tasawuf. Secara etimologi, murìd (isim fa'il dari arada) berarti orang yang menginginkan (rāghib) (Atabik, 1998: 1697), sedangkan arti terminologi, murid adalah "pencari hakikat di bawah bimbingan dan arahan seorang pembimbing spiritual (mursyid)" (Abdul Mudjib, 2008: 104). Penggunaan isitilah ini tampaknya dilatarbelakangi pimpinan MTI di era awal, pada umumnya memang pengamal tarekat, atau paling tidak mempertahankan ajaran tarekat yang mu'tabarah (Alaiddin Koto, 1996: 21). Jadi, dari istilah yang digunakan untuk sebutan peserta didik, MTI berbeda dengan pesantren. Di pesantren, peserta didik disebut dengan santri.

Menurut Dhofier (1988: 52-52), santri tersebut ada dua bentuk, pertama, santri mukim, yaitu murid-murid yang berasal dari daerah yang jauh dan menetap dalam kelompok pesantren, atau 
pondok atau asrama. Kedua, santri kalong, yaitu murid-murid yang berasal dari desa-desa di sekeliling pesantren, yang biasanya tidak menetap dalam pesantren. Untuk mengikuti pelajarannya di pesantren, mereka bolak-balik (nglajo) dari rumahnya sendiri.

Di lingkungan MTI, murid dalam pengertian santri mukim dan kalong juga ditemukan. Akan tetapi, tidak digunakan istilah khusus terhadap mereka. Selain itu, murid-murid MTI yang berasal dari daerah jauh tidak pula semuanya tinggal di asrama yang disediakan oleh madrasah, karena biasanya ketersediaan asrama itu terbatas sehingga di antara mereka ada yang tinggal di rumah-rumah penduduk. Maka hubungan mereka dengan masyarakat sekitar demikian eratnya.

Perlu pula ditegaskan bahwa murid-murid yang belajar di MTI ini memiliki sebutan tersendiri pula bagi masyarakat sekitar. Umumnya mereka disebut dengan istilah urang siak. Namun ada pula sebutan khusus sesuai dengan kebiasaan masyarakat lokal setempat. Misalnya, di MTI Jaho, masyarakat sekitar menganggap murid MTI bukan tamu, tetapi sebagai "anak nagari”. Kemudian, masyarakat di sekitar MTI Jaho memanggil murid laki-laki dengan sebutan "ustadz", walau pun masih kelas I, sedangkan untuk murid perempuan dipanggil dengan sebutan shabian. Sebagian murid MTI Batang Kabung dipanggil oleh masyarakat setempat dengan sebutan "buya". Murid-murid senior di MTI Pasir dipanggil pula dengan sebutan "Tuanku". Sedangkan di Batang Kabung, sebutan Tuanku itu digunakan setelah mereka tamat dilakukan pengangkatan secara resmi atas izin gurunya.

Namun belakangan, khususnya setelah istilah pesantren masuk dalam Undang-Undang Nomor 20 Tahun 2003 tentang Sistem Pendidikan Nasional, lalu pesantren menjadi salah satu Direktorat, yaitu Direktorat Pendidikan Diniyah dan Pondok Pesantren di bawah Ditjen Pendidkan Islam Kementerian Agama, maka MTI juga menggunakan nama Pondok Pesanteren di belakangnya. Akibatnya, murid-murid MTI pun biasa dipanggil dengan sebutan "santri".

6. Masjid/Surau

Dalam tradisi pesantren, masjid menjadi elemen penting.

40 | Tradisi Madrasah Tarbiyah Islamiyah 
Masjid dianggap sebagai tempat yang paling tepat untuk mendidik para santri, terutama dalam praktek sembanyang lima waktu, khutbah dan sembahyang jumat, dan pengajaran kitabkitab Islam klasik (Dhofier, 1988: 49).

Masjid juga menjadi elemen penting dalam proses pendidikan di MTI. Karena itu, pemanfaatan masjid sebagai media pendidikan Islam bagi santri juga patut disebut sebagai salah satu tradisi MTI. Hanya saja, umumnya masjid tidak berdiri di dalam kompleks MTI. Bahkan tidak semua MTI berdampingan dengan masjid. Karena itu, masjid lebih diberdayakan sebagai tempat untuk melatih sekaligus praktik berdakwah, khutbah jumat, dan imam shalat lima waktu.

Tidak terdapatnya masjid di komplek MTI juga terkait dengan kultur masyarakat Minangakabau. Dalam bernagari, masjid merupakan syarat yang harus ada, di samping bangunan fisik lainnya (ada tujuh syarat fisik bernagari 1) basosok bajurami; 2) balabuah batapian; 3) barumah batanggo; 4) bakorong bakampuang; 5) basawah baladang; 6) babalai bamusajik; dan 7) bapandam pakuburan, lihat Amir M.S., 2006: 52-55).

Pendeknya, masjid itu milik masyarakat dalam setiap nagari. Akan tetapi, masyarakat setempat biasanya menyambut baik keberadaan dan kehadiran murid-murid MTI. Apalagi jika murid MTI itu telah di kelas tinggi dan dinilai mampu menjadi imam, khatib atau penceramah, maka masyarakat setempat biasanya memberikan kesempatan kepada mereka untuk tampil ke depan. Dalam hal ini, masjid menjadi sarananya.

Tidak saja masjid, di setiap suku juga memiliki surau atau semacam mushalla yang berfungsi sebagai tempat belajar membaca al-Qur'an melaksanakan shalat lima waktu secara berjamaah. Di surau ini, murid-murid MTI juga biasanya terlibat aktif di dalamnya. Bahkan sebagian murid-murid MTI tersebut ada yang tinggal di surau ini sebagai marbot (garin) sekaligus menjadi imam shalat dan guru mengaji al-Qur'an bagi anak-anak masyarakat setempat. Hingga saat ini, tradisi ini masih bertahan di MTI Batang Kabung. Baik alumni yang telah menjadi Tuanku maupun santri kelas VII (calon Tuanku) yang dipercaya oleh pimpinan MTI, tinggal di masjid dan surau untuk menjalankan tugas di atas. Begitu juga masjid Tarbiyah di Canduang dan 
Masjid Jaho juga yang menjadi garin di sana adalah santri MTI itu sendiri.

7. Pondok atau asrama

Sebelum adanya lembaga pendidikan Islam yang menerapkan sistem klasikal seperti MTI, surau menjadi lembaga pendidikan Islam di Minangkabau. Di surau, tidak dikenal istilah asrama atau pondok, sebab peserta didik yang masih belum remaja atau pemuda yang belum menikah tidur di surau tersebut. Karena itu pula Zamakhsyari Dhofier (1988: 45) menyebutkan bahwa sistem asrama di pesantren yang ada di Jawa berbeda dengan sistem pendidikan surau di daerah Minangkabau. Namun, setelah pendidikan Islam mengalami perubahan dari surau menjadi MTI, maka MTI pun tampil seperti pesantren yang menyediakan asrama atau pondok. Tersedianya pondok ini disebabkan adanya santri yang berasal dari daerah lain yang jauh dari MTI tersebut sehingga tidak memungkinkan mereka untuk pulang-balik. Umumnya, MTI menyediakan pondok asrama, meskipun ada juga MTI yang tidak menyediakan asrama karena santri yang belajar hanya masyarakat di sekitar MTI tersebut.

Pondok atau asrama ini tidak saja dijadikan sebagai tempat istirahat bagi santri saja, tetapi juga sebagai tempat belajar. Apalagi pondok yang ditinggali oleh santri senior yang memiliki kemampuan lebih di mata santri, mereka menjadi guru tuo dan dikunjungi oleh santri yunior untuk belajar atau menanyakan kaji yang sulit, sebagaimana yang telah dikemukakan di atas.

Bagi MTI yang berjauhan jaraknya dengan masjid, maka disediakan pula di asrama ini ruangan semacam aula untuk melaksanakan shalat berjamaah sekaligus tempat belajar seperti muhādharah, mudzākarah, dan sebagainya. Asrama semacam ini masih ditemukan hingga kini di asrama MTI Batang Kabung yang biasanya mereka sebut dengan nama anjuang. Hanya saja, di anjuang ini lebih digunakan sebagai tempat belajar, sementara shalat berjamaah hanya Ashar atau ketika hari hujan lebat sehingga tidak memungkinkan untuk shalat ke surau yang ada di kampus II, komplek MTs dan berjarak sekitar 300 meter.

\section{Penutup}

42 | Tradisi Madrasah Tarbiyah Islamiyah 
Demikianlah beberapa tradisi MTI yang tumbuh dan berkembang sejak awal berdirinya hingga sekarang. Namun tidak semua tradisi itu berjalan persis sama seperti awal perkembangannya. Jika pun tradisi itu masih ada, tetapi beberapa di antaranya cenderung menurun kualitas pelaksanaannya. Misalnya, sistem pembelajaran munāzhara $\underline{h}$, mudzākarah , begitu juga kaji batungkuihan dengan guru tuo. Begitu pula kehadiran Syekh atau Buya sebagai pimpinan dan panutan santri di lingkungan MTI sekaligus tempat bertanya bagi masyarakat sekitar, mulai mengalami kelangkaan. Demikian pula praktek tarekat, beberapa MTI yang dulunya terdapat kegiatan tarekat, seperti suluk di MTI tersebut, kini tidak ditemukan lagi. Hal ini terjadi di MTI Canduang. Semasa Syekh Sulaiman ar-Rasuli, setiap Ramadhan mereka berkhalwat di asrama putri, karena santri diliburkan. Meskipun yang anggota khalwat adalah masyarakat setempat, bukan santri-santrinya, tetapi bisa dikatakan tarekat Naqsyabadiyah ketika itu menjadi bagian dari tradisi MTI karena pimpinannya adalah pemimpin dari MTI Canduang itu sendiri dan tempatnya dilakukan di MTI Canduang.

Meskipun demikian, pengaruh budaya lokal-Minangkabau, mempengaruhi tradisi MTI itu sendiri. MTI sebagai aset penting di ranah Minang memang dituntut untuk terbuka terhadap perubahan ke arah yang lebih baik, tetapi perlu tetap mempertahankan tradisinya, apalagi terkait dengan identitasnya sebagai lembaga pendidikan Islam yang berorientasi kepada tafaqquh fi al-din, berpaham ahl alsunnah wa al-jama'ah dan bermazhab Syafi'i.

\section{Daftar Kepustakaan}

Abbas, Siradjuddin, I'tiqad Ahlussunnah Wal-Jamaah, Jakarta: Pustaka Tarbiyah Baru, 2010, cet. Ke-9

, Sejarah dan Keagungan Madzhab Syafi'i, Jakarta: Pustaka Tarbiyah Baru, 2010, cet. ke-17

Ali, Atabik dan Ahmad Zuhdi Muhdlor, Kamus Kontemporer Arab-Indonesia, Yogyakarta: Multi Karya Grafika Ponpes Krapyak, 1998, cet. ke-8

Azra, Azyumardi, Surau; Pendidikan Islam Tradisional dalam Transisi dan Modernisasi, Jakarta: Logos Wacana Ilmu, 2003

Daman, Rozikin, Membidik NU: Dilema Percaturan Politik NU Pasca 
Khittah, Yogyakarta: Gema Media, 2001

Dhofier, Zamakhsyari, Tradisi Pesantren: Studi tentang Pandangan Hidup Kyai, Jakarta: LP3ES, 1994, cet. ke-6

Fateh, Kholil Abu, Mengungkap Kebenaran Aqidah Asy'ariyyah: Meluruskan Distorsi terhadap Abu al-Hasan al-Asy'ari dan Ajarannya, Ciputat: Pustaka Ta'awun, 2012

Hamka, Ayahku, Djakarta: Widjaya, 1950

Koto, Alaiddin, Pemikiran Politik Persatuan Tarbiyah Islamiyah 19451970, Pekanbaru: Susqa Press, 1996

Latief, M. Sanusi, Gerakan Kaum Tua di Minangkabau, Disertasi: IAIN Syarif Hidayatullah Jakarta, 1988

M.S., Amir, Adat Minangkabau: Pola dan Tujuan Hidup Orang Minang, Jakarta: Mutiara Sumber Widya, 2006, cet. ke-5, hal. 202-203

Madjid, Nurcholish, Bilik-bilik Pesantren: Sebuah Potret Perjalanan, Jakarta: Paramadina, 1997

Majalah Soearti Nomor 20 Tahun II, Zulqaidah 1357 H/Januari 1939 M

Majalah Soearti Nomor 5 Tahun I, Sya'ban 1356 H/Oktober-Nopember 1937, hal. 11

Mardhiyah, Kepemimpinan Kiai dalam Memelihara Budaya Organisasi, Malang: 2012

Mastuhu, Dinamika Sistem Pendidikan Pesantren; Suatu Kajian tentang Unsur dan Nilai Sistem Pendidikan Pesantren, Jakarta: INIS, 1994

Muhammad, Husein, "Kontekstualisasi Kitab Kuning: Tradisi Kajian dan Metode Pengajaran," dalam Marzuki Wahid, dkk ed., Pesantren Masa Depan: Wacana Pemberdayaan dan Transformasi Pesantren, Bandung: Pustaka Hidayah, 1999

Munawwir, A.W., Kamus al-Munawwir Arab-Indonesia Lengkap, Surabaya: Pustaka Progressif, 1997

Nata, Abuddin, Sejarah Sosial Intelektual Islam dan Institusi Pendidikannya, Jakarta: Rajawali Pres, 2012

Penghulu, M. Sayuti Dt. Rajo (ed.), Tau Jo Nan Ampek Pengetahuan yang Empat Menurut Ajaran Adat dan Budaya Alam Minangkabau,

44 | Tradisi Madrasah Tarbiyah Islamiyah 
t.t.: Mega Sari Kerjasama Sako Batuah, 2005 , "Perangkat Adat dalam Struktur Masyarakat Minangkabau," dalam LKAAM Sumatera Barat, Bunga Rampai Pengetahuan Adat Minangkabau, (Padang: Yayasan Sako Batuah, 2000

Umiarso dan Nur Zazin, Pesantren di Tengah Arus Mutu Pendidikan: Menjawab Problematika Kontemporer Manajemen Mutu Pesantren, Semarang: RaSAIL Media Group, 2011

Yunus, Mahmud, Kamus Arab-Indonesia, Jakarta: Hidakarya Agung, 1990, cet. ke-8 